\title{
Efektifitas Pembelajaran Kitab Akhlak Lil Banin Dalam Membentuk Akhlak Santri Pondok Pesantren Miftahul Jannah Karang Jaya
}

\author{
Suwita Dela, Masudi, Eka Yanuarti
}

IAIN Curup, Bengkulu, Indonesia

Suwitadela460@gmail.com, masudialwi70@gmail.com, ekayanuarti@iaincurup.ac.id

\begin{tabular}{ll}
\hline & Abstract \\
\hline Article History & Researcher Conducted research on \\
Received:05-08-2020 & Diniyah madrasah education which \\
Revised :08-09-2020 & consisted of two classes for volume one and \\
Accepted:12-09-2020 & two consisting of 65 students and for \\
\hline Keywords: & volume three and four consisting of 32 \\
Effectiveness & students. In this study, the objectives are \\
Book & first to determine the effectiveness in the \\
Morals & learning process of lilbanin morals, second \\
Lil banin & to determine the effectiveness in shaping \\
& the morals of students in learning lil banin \\
& morals. descriptive qualitative research \\
& type. The conclusion is that the \\
& effectiveness of lil banin moral learning is \\
& quite good and has been very effective even \\
& though learning the lil banin book is a \\
& yellow book learning, so that the delivery \\
& of material is easy to understand by using \\
& attractive and appropriate methods such as \\
& exemplary methods, refraction, sorogan, \\
& wetonan, bandungan and memorization so \\
& that achieved in the formation of santri \\
& morals.
\end{tabular}

\section{Pendahuluan}

Di Era 4.0 seperti sekarang ini globalisasi telah melanda dunia, yang semulanya proses pembelajaran terbatas oleh ruang dan waktu namun di era sekarang proses pembelajaran bisa diperoleh dimanapun dan kapanpun. Dan di era sekarang yang canggih dan digital maka akan berpengaruh pula dengan akhlak, perilaku, etika, moral 
dikarenakan mudahnya mengakses internet sehingga hal-hal yang belaknagn ini terjadi muncul seperti batasan anatara pornografi dan pornoaksi dengan seni sangat tipis. Dan sulit dibedakan apakah pakaian ketat dan minim termasuk pornoaksi atau bagian dari seni.Untuk mempertahankan nilai-nilai agar tidak luntur maka harus ada penguatan dalam hal ini dibutuhkan penguatan nilai berdasarkan Al-Qur'an dan Hadits.(Ruhaini Dwi Lestari R. , 2016).

Di negara Indonesia merupakan negara hukum sangat menjunjung tinggi harkat dan martabat dalam menjamin setiap warga negaranya yang tercantum dalam pembukaan UUD 1945 yang menjelaskan bahwa kemerdekaan adalah hak segala bangsa Indonesia. Dalam hal ini berlaku juga dalam dunia pendidikan. (Eka Yanuarti 2019). Didalam dunia pendidikan tidak bisa dilepaskan dengan perkembangan teknologi.Sarana pendidikan yang modern ikut serta dalam mengoptimalisasi kegiatan belajar mengajar, sarana pendidikan yang modern ini tidak hanya digunakan dalam lembaga tingkat sekolah tetapi juga digunakan dalam kehidupan sehari-hari. Perkembangan teknologi terutama teknologi informasi dan komunikasi sangat membantu dan memberikan kemudahan dalam pembelajaran serta dapat merubah paradigma segala informasi hanya dapat diperoleh dari guru/dosen di sekolah menjadi belajar bisa diperoleh dimana saja dan kapan saja.(Rinaldi, 2017) Pendidikan memegang peranan yang sangat penting dalam mewujudkan suatu tujuan pendidikan nasional sebagaimana yang tercantum dalam UU No. 20 Tahun 2003 tentang sistem pendidikan nasional.(Yanuarti 2018)

Dalam mencapai tujuan pembelajaran maka harus diperbaiki terlebih dahulu proses komunikasi dalam penyampaian pesan informasi agar dapat merangsang pikiran, perasaan serta minat peserta didik. Salah satu upaya yang dilakukan dalam mencapai tujuan tersebut adalah dengan memperbaikan materi atau bahan ajar dengan mengoptimalisasi media.Dengan mengoptimalisasi media pembelajaran diharapkan dapat menumbuhkan kretifitas guru serta program yang direncakan sesuai dengan karakteristik dan kebutuhan peserta didik.(Fahyuni, 2016)

Pendidikan adalah hal pertama yang didapatkan oleh manusia, karena sejak manusia lahir sampai ia meninggal maka sampai saat itu pula manusia akan terus mendapatkan pendidikan, baik yang mereka sadari atau tidak. Pendidikan dijadikan alat atau sarana manusia untuk 
mengetahui apa yang ada dan sedang berkembang dilingkungan dan mereka. Pendidikan menurut Dahlan mengatakan bahwa tujuan menciptakan manusia yang baik budi, yaitu alim dalam agama; luas pandangan, yaitu alim dalam ilmu-ilmu umum; bersedia berjuang untuk kemajuan masyarakat.Namun, pendidikan tidak hanya tentang pendidik dan peserta didik.Lingkungan juga menjadi sumber pendidikan bagi seseorang. Pendidikan didapatkan melalui contohcontoh nyata yang ada di sekitar, dimana mereka melihat dan menemukan secara langsung tentang suatu pengetahuan yang baru (ABIDIN, 2019)

Yang menjadi permasalahan yang sering muncul dalam pengajaran terutama dalam pengajaran agama Islam adalah mengenai cara menyajikan materi atau bahan ajar kepada peserta didik sehingga dapat memperoleh hasil belajar yang maksimal. Selain itu juga ditemukan permasalahan bahwa guru kurang menggunakan metode yang bervariasi.(Sutomo, 2019)

Kegiatan belajar mengajar disekolah merupakanstackholder dalam pendidikan formal sebagai upaya untuk mengarahkan perubahan dalam diri peserta didik secara sistematis dan terencana yang meliputi segala aspek baik dari segi kognitif, afektif maupun psikomotorik. Dalam mencapai proses pembelajaran ada beberapa komponen yang mempengaruhi didalamnya yaitu pendidik, peserta didik, bahan ajar, metode pembelajaran, fasilitas pendidikan, lingkungan dan beberapa komponen pendukung lainnya dalam mendukung dan menunjjang semangat peserta didik.(Erwinsyah, 2017)

Miarso mengatakan bahwa efektivitas dalam sebuah pembelajaran merupakan salah satu standart mutu pendidikan yang diukur dengan tercapainya tujuan pembelajaran, efektivitas dalam pembelajaran dapat juga diartikan sebagai ketetapan dalam mengelola situasi dalam pembelajaran. (Wulansari, 2018)

Akhlak memiliki tingkatan kedudukan paling tinggi dalam kehidupan, sebab rusaknya suatu bangsa disebabkan karena kebobrokan moral atau akhlak warganya. Apabila baik akhlak seseorang maka akan baik juga suatu negara. Akhlak manusia merupakan sesuatu yang diikhtiarkan dan dibiasakan serta dilatih terus menerus.Jika hanya mengandalkan potensi alamiah saja, tidak cukup untuk menjadi seorang yang berakhlak. Tetapi perlu latihan, pembelajaran, penggemblengan dan usaha tanpa henti sehingga 
seorang terbiasa berakhlak yang baik (Abid, 2016)

Pendidikan Agama Islam diharapkan bisa melahirkan manusia yang selalu berusaha dalam menyempurnakan iman, takwa serta berakhlak mulia.Akhlak mulia tercermin dari etika, budi pekerti atau moral yang mulia.Manusia yang memiliki akhlak mulia diharapkan mampu menghadapi, hambatan, tantangan dan perubahan yang muncul dalam pergaulan di masyarakat baik local maupun global.(Edison, 2019)

Konsep akhlak dalam Islam berkaitan erat dengan konsep keimanan. Ketika seseorang mempunyai orientasi dan cita-cita yang tinggi yaitu ridha Allah, maka dengan sendirinya ia akan menganggap rendah apa saja yang bertentangan dengan cita-cita tersebut yaitu seluruh perbuatan atau sifat yang dibenci oleh Allah. Akhlak Islam memiliki beberapa keistimewaan dan ciri-ciri khusus (karakteristik) yang membedakannya dari sistem akhlak lainnya (Bafadhol, 2017).

Adapun penelitian sebelumnya yang mengangkat persoalan penelitian Nur Ali Subhan dengan judul penelitianAkhlak Interaksi sosial antara anak dan orang tua dalam akhlak Lil Banin karya Umar bin Ahmad Braja.Dalam penelitian ini memiliki persamaan dengan penelitian yang diteliti ialah penelitian ini berpusat sama-sama menggunakan kitab akhlak Lil Banin untuk mengukur sejauh mana pembentukan akhlak santri setelah mempelajarinya sedangkan perbedaanya peneliti ini menggunakan pustaka (Lilbrary Resech) metode pengumpulan datanya literatur yang klasik dan modern dan tujuan dari penelitian ini yaitu untuk mengetahui bagimana konsep akhlak interaksi sosial antara akhlak anak dan orang tua dalam kitab akhlak lil banin karya Umar Ahmda Braja sedangkan penelitian yang dilakukan oleh peneliti untuk mengetahui efektifitas pembelajaran akhlak lil banin dalam membentuk akhlak santri pondok pesantren Miftahul Jannah dan peneliti menggunakan metode jenis penelitian kualitatif deskriptif. Penelitian kualitatif deskriptif adalah penelitian yang mendeskripsikan hasil penelitian dengan kata-kata atau kalimat yang pisah-pisahkan menurut kategori sehingga diperoleh suatu kesimpulan. Dapat dlihat kondisi kehidupan sosial yang minim akhlaknya, perlunya perhatian dan tatanan pendidikan akhlak yang harus diterapkan dalam keberlangsungan kehidupan sehari-hari, terlebih penanaman akhlak terhadap peserta didik yang berada di lingkungan agamis yakni pondok pesantren tempat orang menuntut ilmu dan memperbaiki tingkah laku dan perbuatan. Oleh karna itu 
permasalahan diatas peneliti tertarik untuk meneliti Efektifitas pembelajaran kitab akhlak lil banin dalam membentuk akhlak santri pondok pesantren Miftahul Jannah Karang Jaya. lebih lanjut lagi Akhlak yang dimiliki seseorang pada dasarnya tidak dihasilkan dari hasil keturunan dan permbiasaan dan pembiasaan bisa melalui proses pembelajaran yang cukup panjang dan perlu metode yang tepat, dan pendekatan yang tepat.Dengan demikian akhlak merupakan hasil pembiasaan seseorang yang berada di lingkungan sekitarnya.

\section{Metode penelitian}

Penelitian ini menggunakan jenis penelitian kualitatif deskriptif.Penelitian kualitatif deskriptif ini merupakan suatu peneltiain yang menggambarkan hasil penelitian dengan kata-kata atau sebuah kalimat sehingga diperoleh suatu kesimpulan.(Arikunto, 2015: 209)

\section{Sumber Data}

Sumber data dalam penelitian ini ada dua yaitu data pertama data primer yang diperoleh dari hasil wawancara, Kedua data sekunder yang diperoleh dari catatan atau dokumentasi sekolah.

\section{Prosedur Data}

Dikarenakan penelitian ini merupakan penelitian yang bersifat deskriptif, yaitu suatu penelitian yang memiliki tujuan membantu pembaca untuk mengetahui apa yang diterjadi dilingkungan dengan pengamatan, seperti mengenai pandangan parsitipan.(Emzir, 2014: 174). Adapun teknik pengumpulan data dalam penelitian ini yaitu sebagai berikut: Observasi, Wawancara dan Dokumentasi.

Adapun Teknik Analisis Data yang digunakan dalam penelitian ini yaitu Data Miles dan Hubermanmengemukakan bahwa dalam tahapan penelitian kualitatif menggunakan teknik analisis data Reduksi data, Display (Penyajian Data), Penarikan Kesimpulan (Verifikasi). (Miles, 2014: 57).

Teknik analisis data menurut Sugiono adalah untuk menetapkan keabsahan data ini diperlukan untuk memeriksa data berdasarkan sejumlah kriteria tertentu. (Sugiono, 2014: 288). 


\section{Pembahasan}

Paparan tentang hasil penelitian yang didapat berdasarkan hasil observasi, wawancara, dan dokumentasi dari lapangan tentang efektivitas pembelajaran kitab akhlak lil banin dalam memebentuk Akhlak santri di Pondok Pesantren Miftahul Jannah Karang Jaya.Efektif dalam kamus bahasa Indonesia kata efektif adalah ada efeknya (akibatnya, pengaruhnya, kesanya). Jadi efektifitas adalah keefektifan dia ditugasi untuk membantu,Suatu usaha dapat dikatakan efektif jika usaha itu dapat mencapai tujuan. Menciptakan belajar yang efektif penting dilakukan oleh guru,hal ini mengingat belajar yang efektif dapat membantu siswa mampu meningkatkan kemampuan sesuai dengan intruksi intruksional yangingin diciptakan.

Berdasarkan hasil wawancara yang dilakukan oleh K.H. Abdul mu'in bahwa "Pembelajaran yang efektif dalam pembelajaran kitab kuning khususnya pada pembelajaran kitab lil banin itu tidak hanya melihat dari hasil evaluasi yang dicapai santri, akan tetapi mampu memberi pemahaman pada santri sehingga membuat santri menjadi tekun, disiplin, semangat, dan rasa sangat senang dan tertarik dalam belajar. ( wawancara 15 april 2020 )

Hal yang senada yang disampaikan oleh Ustad Ilyas Sidiq selaku pengasuh pondok pesantren Miftahul Jannah beliau mengatakan "Pembelajaran yang efektif yang berada dipondok pesantren Miftahul Jannah bisa dikatakan efektif apabila seorang ustad dalam menyampaikan ilmunya berdasarkan kurikulum yang berada diponpes sedangkan kurikulum yang berada dipondok itu gabungan antara kurikulum dan kurikulum kepondokan dan juga pembelajaran efektif bisa dilakukan dengan menggunakan metodemetode yang menarak sehingga santri yang belajar senang dan semangat dalam pembelajaran dan metode yang sering dipakai dalam pembelajaran kitab lil banin ialah metode bandungan serogan, wetonan, dan hafalan. (wawancara 17 april 2020)

Oleh karena itu banyak sekali faktor yang akan mempengaruhi keefektivitasan pembelajaran karena sangat menuntut tingkat keberhasilan pembelajaran karena efektivitas ialah kegiatan yang dapat diselesaikan dengan waktu yang tepat dan mencapai apa yang ditujuan yan telah direncanakan.

Menurut Warasita efektifitas merupakan kegiatan yang dapat diselesaikan pada waktu yang tepat dalam mencapai tujuan yang diinginkan.efektifitasjuga dapat diartikan sebagai seberapa tingkat 
keberhasilan yang dicapai dari suatu cara tertentu sesuai dengan tujuan yang ingin dicapai. Jadi, efektifitas adalah suatu kegiatan atau usaha yang ingin dilakukan dengan cepat dan tepat serta usaha tersebut telah mencapai tujuannya (Wulandari, 2018)

Ciri-ciri kefektifan suatu program pembelajaran yaitu Berhasilkan mengantarkan siswa mencapai tujuan-tujuan intruksional yang telah ditentukan, Menyalurkan dan menyamapaikan ilmu untuk membiasakan dalam belajar yang atraktif, dan melibat siswa sehingga mencapai tjuan intruksional, Memiliki sarana-sarana yang menunjang proses belajar mengajar, Insentif, yaitu seberapa besar usaha guru memotivasi siswa untuk mengajrkan tugas belajar dan materi belajar yang diberikan. Waktu, pembelajaran akan efektif jika siswa dapat menyelesaikan pelajaran sesuai dengan waktu yang ditentukan. (Sumarni, 2017)

Dengan mengetahui indikator diatas kita dapat mengetahui suatu pembelajaran dapat berjalan efektif jika terdapat minat, sikap dan kemauan dalam diri anak untuk belajar, serta kesiapan diri peserta didik dan guru dalam kegiatan belajar mengajar.(Rohmawati 2015). Beberapa indikator tersebut menerangkan bahwa, keefektifan pembelajaran menjadi sangat penting mengingat tujuan dan hasil belajar yang harus tercapai, sesuai dengan harapan yang diinginkan secara cepat dan tepat.Jadi, dapat disimpulkan bahwa pembelajaran yang efektif adalah pembelajaran yang sesuai target yang diinginkan dengan singkat dan cepat dan tercapainya hasil belajar siswa. Efektifitas menjadi salah satu hal yang penting diperhatikan dalam melaksanakan pembelajaran, agar pembelajaran berjalan sesuai yang diharapkan.Pembelajaran yang efektif adalah pembelajaran yang dapat menghasilkan belajar yang bermanfaat dan terfokus pada siswa (studentcenterented) melalui penggunaan prosedur yang tepat. Ada beberapa indicator pembelajaran yang efektif, diantaranya : Kualitas pembelajaran, dan Kesesuaian tingkat pembelajaran (Nurdiansyah, 2016)

Efektivitas pembelajaran merupakan ukuran tingkat keberhasilan suatu sekolah dalam menyelenggaran pendidikan, efektivitas dalam pembelajaran sangat diperlukan dalam upaya pembelajaran membangkitkan minat dan motivasi anak di dalam proses pembelajaran agar seluruh potensi dan kompetensi dalam diri anak dapat berkembang. (Yaumi, 2017) 
Oleh karena itu mengajar secara efektif sangat berpengaruh besar terhadap pemilihan dan penggunaan metode pembelajaran .dengan menggunakan metode pembelajaran, proses belajar mengajar Nampak sangat menyenangkan dan membuat siswa dapat menangkap ilmu dari pendidik dengan mudah. Metode pembelajaran merupakan suatu cara atau jalan yang ditempuh oleh pendidik dalam menyampaikan materi pembelajaran agar tercapai tujuan pembelajaran yang diharapakan. (mahmud, 2017)

Berdasarkan hasil wawancara yang dilakukan oleh peneliti kapada ustad Ahmad Misbah ulumin munir bahwa "Salah satu keberhasilan pembelajaran terletak pada metode pembelajaran guna membangkitkan minat belajar peserta didik dengan cara mengajar yang menarik sesuai perkembangan peserta didik dan menggunakan media pembelajaran yang menarik agar minat belajar tumbuh dengan sendirinya pada peserta didik,pada saat ini waktu pembelajaran akhlak lil banin yang diterapkan pada pondok pesantren miftahul janah yaitu 2 kali dalam seminggu, yaitu pada ba'da subuhdan ba'da ashar. "(wawancara 29 april 2020 ).

Selanjutnya berdasarkan wawancara yang dilakukan oleh peneliti kepada Ustad Toat Muhajjir selaku pendidik di pondok pesantren Miftahul Jannah beliau mengatakan bahwa "Untuk meningkatkan pembelajaran yang efektif maka santri-santri yang mengikuti pembelajaran yang berada dipondok pesantren wajib memiliki kitab-kitab,apa lagi kitab lil banin yang merupakan bagian dari kitab kuning oleh karna itu dengan mereka memiliki kitab tersebut maka proses pembelajar bisa dilakukan dengan mudah, dan bisa berjalan sesuai yang diharapkan apabila waktu pembelajaran telah seslesai merekapun masih bisa mengulang-ulang ataupun belajar kembali di asramanya"

Oleh karena itu suatu pembelajaran bisa dikatakan efektif, apa lagi pada pembelajaran yang tidak semua guru bisa menyampaikanya kepada siswa maka dari segi kesiapan guru,materi, metode dan lainlainya harus dipenuhi sehingga apa yang diinginkan akan tercapai dan terpenuhi.

Selain itu dibawah ini ada beberapa metode pembelajaran pesantren yang menjadi ciri khas pesantren, yaitu sorgan, wetonan, bandungan, menghapal, dan musyawarah. Pertama, Sorogan; adalah sistem pengajaran dengan pola sorogan dilaksanak didikan dengan jalan santri yang biasa pandai menyorog-kan sebuah kitab kepada kiai 
atau ustadz. Dalam sistem ini, seorang santri/peserta didik harus betul-betul menguasai ilmu yang dipelajarinya sebelum mereka dinyatakan lulus, karena sistem ini dipantau langsung oleh kyai/ustadz.Dalam perkembangan selanjutnya sistem ini jarang dipraktekkan dan ditemui karena memakan waktu yang lama. Kedua, Wetonan; sistem pengajaran dengan jalan wetona inidilaksanakan dengan jalan kyai/ustadz membaca suatu kitab dalam waktu tertentu dan santri dengan membaca kitab yang sama mendengarkan dan menyimak bacaan kyai/ustadz. Ketiga,musyawarah; metode ini merupakan metode pembelajaran yang lebih mirip disksui atau seminar. Beberapa santri dengan jumlah tertentu membentuk halaqah yang dipimpin langsung oleh kyai dan ustad untuk membahas dan mengkaji materi atau persoalan yang ditentukan sebelumnya.Dalam pelaksanaannya, santri bebas untuk mengajukan pertanyaan atau pendapat.

Metode pembelajaran multak digunakan dalam kegiatan belajar mengajar haruslah bervariasi agar proses pembelajaran yang berlangsung tidak membosankan. (Nurjanah, 2019) Menurut hasil wawancara yang dilakukan pada Ustad misbah ulumun munir S.Pd. beliau mengatakan bahwa "Pembentukan akhlak dapat dilakukan dengan proses pembelajaran yaititu ketika menyampaika pembelajaran dalam menyampaikan materi pembelajaran harus menggunakan metode-metode yang tidak membosankan,sehingga sehingga santri lebih nyaman dan cepat memahami terhadap pembelajaran itu" (wawacara 29 april 2020)

Oleh karena itu Dalam pembelajaran yang akan dilakukan oleh ustad dalam menyampaika pembelajaran harus menggunakan menerapakan metode-metode yang berbeda-beda agar tidak membosankan dan harus pandai dalam memilih metode tersebut agar supaya sesuai dengan materi yang akan disampaikan.

Dalam Proses pembelajaran kitab tersebut seperti biasanya, mengunakan metode ceramah, tanya jawab dan bandongan".Oleh karena itu, tidak hanya menggunaka satu metode saja dalam pembelajaran tetapi menggunakan beberapa metode dalam kegiatan belajar mengajar.Berdasarkan hasil wawancara yang penulis lakukan, ada beberapa macam metode yang digunakan dalam pembelajaran kitab Akhlak Lil Baniin. Pembelajaran dalam kitab Akhlak Lil Baniin ini menggunakan metode, bandungan, ceramah dan tanya jawab. (Farikhah, 2019) 
Dalam kitab Akhlak Lil Banin terdiri dari 4 juz, dari keempat juz ini masing-masing juz menjelaskan tentang akhlak dengan kisahkisah. Pada juz 1, menggunakan kisah-kisah yang merupakan rekaan saja yang mudah dipahami dan dimengerti oleh anak perempuan dan laki-laki.Pada juz 2, banyak didominasi oleh kisah-kisah yang bersumber dari Al-Qur'an maupun hadist dan dijilid ini pun pembelajarannya untuk anak laki-laki dan perempuan.Pada juz 3, pembelajarannya menggunakan kisah-kisah yang bersumber dari Alqur'an maupun hadist dan dikhususkan untuk anak perempuan saja. Sedangkan pada juz terakhir yaitu juz 4, Syekh Ahmad bin Umar Baraja dalam kitabnya menggunakan kisah para sahabat-sahabat. Pada pembelajaran ini juga akhak anak yang diajarkan tidak memiliki batasan usia yang spesifik, hanya saja akhlak-akhlak yang terkandung dalam kitab Akhlak Lil Banin ini berisikan akhlak seorang anak yang berkisar antara umur 6 sampai dengan sebelum akil baliqh. ( ABIDIN, 2019)

Berdasarkan hasil wawancara yang dilakukan peneliti kepada ustad Mamdu "Pembentukan akhlak dapat dibentuk dari Pembiasaan,bawaan lahir, lingkungan sekitar, dan pergaulan dan dengan cara mengajarkan pembelajaran akhlak lil banin yang materi ajarnya tentang berakhlak yang baik kepada pencipta dan berakhlak baik kepada manusia yang tujuan pembelajaran untuk membentuk akhlak santri yang baik maka senada dengan pembentukan akhlak santri itu bisa dibentuk dari pembiasaan melalui penyampai materi ajar yang menarik ( wawancara 5 mei 2020). Selanjutnya hal yang senada yang disampaikan oleh Ustad K.H Abdul Mu'in pimpinan beliau mengatakan bahwa "Pembentukan Akhlak dapat dibentuk melalui proses pembelajaran, proses pendekatan, dan proses pembiasaan serta melalui suatu pembelajaran kitab Akhlak lil banin yang mengajarakan para santri untuk menjadikan santri yang berakhlakul karimah melalui materi pembelajaran, metode pembelajaran yang diajarkan sehingga para santri memahami dan tertarik serta semangat dalam mengikuti pembelajaran tersebut"

Oleh karena itu peneliti menyimpulkan bahwa pembentukan akhlak dapat dilihat dan dapat dibentuk oleh berbagai hal yang harus kita pahami yang harus kita ketahui. Karna pembentukan akhlak bisa dari hasil keturunan, hasil dari lingkungan terdekat, hasil dari suatu proses pembelajar, proses pembiasaan yang lambat laun menjadikan sebagai tingkah laku yang akan melekat pada diri seseorang. 
Dalam Kamus Besar Bahasa Indonesia pembentukan diartikan proses, cara, perbuatan membentuk. Secara Bahasa akhlak merupakan bentuk jamak dari khuluq yang memiliki arti budi pekerti, perangai, tingkah laku dan tabiat. Akhlak berakar dari kata kholaqa yang memiliki arti menciptakan.(Syarifudin,2016)

Dalam pembentukan akhlak menurut pendidikan Islam yaitu haruslah berlandaskan dari Al-Qur'an dan hadist orang berpegang teguh kepada Al-Qur'an dan hadist diharapkan dapat mewujudkan kehidupan yang bahagia dunia dan akhirat.(Wardati, 2018)

Dalam pembentukan suatu akhlak memiliki tujuan agar membentuk kepribadian manusia yang memiliki akhlak yang mulia.Akhlak mulia tercermin dari perilaku yang baik yang berlandaskan akhlak-akhlak yang ada di dalam Al-Qur'an dan hadits. (Oktaviani, 2017)

\section{Keteladanan}

keteladanan merupakan salah satu metode yang paling efektif dalam membentuk akhlak mulia dalam diri seseorang, karena akhlak mulia akan diterapkan apabila ada model yang sesuai untuk ditiru seorang yang menyampaikan sesuai dengan perilaku yang ia sampaikan.

\section{Pembiasaan}

Pembiasaan adalah metode yang sangat penting untuk diterapkan karena akhlak mulia apabila diterapkan dengan kebiasaan atau terus-menerus akan memunculkan kepribadian.

\section{Memberi Nasihat}

Memberi nasehat adalah metode dalam menjelaskan kebenaran dan kemaslahatan agar orang yang dinasehati terhindar dari bahaya serta menunjukannya ke jalan bahagia dan bermanfaat. (Nofiaturrahmah, 2018)

Menurut Al Ghazali dalam pembentukan akhlak anak beliau menawarkan sebuah konsep pendidikan yang memiliki tujuan untuk mendekatkan diri kepada Allah. Mendekatkan diri kepada Allah merupakan cerminan kesempurnaan manusia dan untuk mendekatkan diri kepada Allah ada jembatan yang harus dilalui yaitu ilmu pengetahuan. Ibn Maskawaih menambahkan dalam mengajarkan akhlak tidak ada materi yang spesifik tetapi materi yang diajarkan dalam pendidikan akhlak dapat diaplikasikan ke dalam banyak ilmu asalkan tujuan utamanya adalah bertaqwa kepada Allah.( Ainiyah, N. 2013).Guru untuk proses belajar mengajar memiliki peranan dan 
tanggung jawab yang sangat besar. Selain itu tanggung jawab guru sangat besar pengaruhnya dalam pembentukan akhlak anak. Dengan menggunakan, memilih, menetapkan metode yang tepat, yang pada akhirnya dapat terwujud dan menghasilkan pembentukan akhlak anak (Jannah, 2017)

Dalam pembentukan akhlak sama halnya berbicara mengenai tujuan pendidikan, tujuan merupakan sasaran atau maksud. Tujuan pendidikan secara Istilah dapat diartikan sebagai suatu perbuatan yang diarahkan kepada tujuan tertuntu yang hendak dicapai melalui upaya dan usaha. (Warasto, 2018)

Tujuan pendidikan Islam merupakan mengembangkan nilainilai Islami dalam jiwa manusia. Menurut M. Arifin tujuan dari Pendidikan Islam yaitu untuk mewujdukan nilai-nilai Islami dalam diri manusia yang diusahakan oleh pendidik muslim melalui proses agar terwujudlah pribadi yang beriman, berwawasan luas serta menjadi hamba Allah yang bertaqwa. (Warasto, 2018)

Oleh karena itu, Kitab Akhlak Lil Banindisebut sebagai kitab metode belajar, tetapi tampaknya dikalangan pesantren ada kecenderungan untuk menyebukan bahwa etika santri, terutama kepada gurunya merupakan salah satu perangkat untuk memperoleh ilmu. Dan yang menjadi sasaran pengajaran kitab ini adalah perubahan akhlak menuju yang lebih baik bagi para santri. Pendidikan akhlak penting artinya bagi manusia dan setiap warga Negara. Dalam pendidikan Islam tujuan pokok dan utama merupakan esensi pembuntukan ahklak manusia.hal ini karena setiap bangsa dan warga Negara mengharap generasi penerusnya dapat lebih baik dari generasi sebelumnya. Pendidikan agama selama ini mengharuskan peserta didiknya tidak boleh ada kesalahan. Padahal seorang pribadi itu tunduk kektika ada pengalaman salah. Akibatnya pendidikan agama cenderung melahirkan mental heteronomy. Artinya, kebaikan sesungguhnya yang tidak tumbuh secara autentik dari dalam, tetapikebaikan itu ditandai dengan ketundukan ( Mualih, M. 2019)

Perlahanlahan sikap/nilai-nilai luhur yang ditanamkan tersebut akan terealisasikan ke dalam dirinya dan membentuk kesadaran sikap dan tindakan sampai usia dewasa.

\section{Faktor Internal}

Dalam faktor internal meliputi sebagai berikut yaitu: 


\section{Insting atau Naluri}

Insting merupakan karakter yang mendarah daging dalam jiwa seseorang yang dibawa sejak lahir.

\section{Adat atau kebiasaan}

Adat atau kebiasaan merupakan suatu tindakan dan perbuatan seseorang yang dilakukan secara berulang-ulang sehingga menjadi suatu kebiasaan.

\section{Keturunan}

Keturunan adalah berpindah sifat-sifat orang tua kepada anak.

\section{Faktor Eksternal}

Faktor eksternal yaitu faktor yang berasal dari luar individu yang berpengaruh baik secara langsung maupun tidak langsung. Faktor eksternal meliputi yaitu sebagai berikut:

\section{Lingkungan Alam}

Lingkungan alam dapat berpengaruh terhadap perangai atau karakter seseorang, seseorang yang hidup dilingkungan yang tandus, gersang dan manus akan berbeda dengan orang yang hidup di subuh dan sejuk.

\section{Lingkungan Pergaulan}

Seseorang yang hidup dilingkungan yang baik akan tumbuh atau muncul kepribadian yang baik, begitu juga sebaliknya. (Zubaedi, 2017)Dan lingkungan pergaulan yang sangat berpengaruh dalam diri seseorang yaitu pola asuh yang diterapkan oleh orang tua. Pola asuh ini meliputi cara menjaga atau merawat anak, membimbing serta melatih anak.(Yanuarti 2019)

\section{Simpulan}

Berdasarkan hasil penelitian diatas beserta pembahasan yang sudah diuraikan diatas,diperoleh kesimpulan sebagi berikut : efektifitas pembelajaran akhlak lil banin dalam pembentukan akhlak santri sudah cukup baik dan efektif sudah melibatkan elemen-elemen Pembelajaran yang efektif. Walaupun dalam penyampaian materi tidak memakai Rps,ataup Rpp dan tidak terlalu mementingkan Administrasi perangkat pembelajaran. akan tetapi, dengan cara ustad menyampaikan pembelajaran yang menarik dan mudah dipahami oleh 
166 Suwita Dela, Masudi, Eka, Efektifitas Pembelajaran ....

santri ilmu yang telah di sampaikan melalui pendekatan metode pembiasaan,metode keteladanan, metode bandongan, metode sorogan, smetode menghafal. agar pondasi kehidupan dan hati para santri menjadi akhlak santri yang baik. 


\section{DAFTAR PUSTAKA}

Abid, R. 2016. Pembelajran Akhlak dengan Menggunakan Kitab Akhlak Lil Baniin di Pondok Pesantren Darut Tauchid Al 'Alawiyah Al Awwaliyah Dawung Koripan Tegalrejo Kabupaten Magelang (Doctoral dissertation, Fakultas Tarbiyah dan Ilmu Keguruan).

Abidin, M. Z., \& Assegaf, J. F. 2019. Pembelajaran Kitab Akhlak Lil Banin Bagi Orang Tua Untuk Mendidik Anak Di Tpa Nurul Ihsan Desa Jenar Kecamatan Jenar Kabupaten Sragen Tahun 2019 (Doctoral dissertation, IAIN Surakarta).

Ananda, R., \& Amiruddin, A. 2019. Perencanaan Pembelajaran.

Bafadhol, I. 2017. Pendidikan Akhlak Dalam Perspektif Islam.Edukasi Islami: Jurnal Pendidikan Islam, 6(02), 19.

Edison, E. 2019. Pendidikan Karakter dan Implementasinya.JOEAI: Journal of Education and Instruction, 2(2), 66-82.

Eka Yanuarti, D. Y. 2019. Upaya perangkat desa air hitam kecamatan ujan mas dalam mencegah timbulnya tindakan asusila. Nuansa, vol. XII,.

Erwinsyah, A. 2017. Manajemen kelas dalam meningkatkan efektifitas proses belajar mengajar. TADBIR: Jurnal Manajemen Pendidikan Islam, 5(2), 87-105.

Fahyuni, E. F., \& Istikomah, I. 2016. Psikologi Belajar \& Mengajar (kunci sukses guru dalam interaksi edukatif).

Mahmud, S., \& Idham, M. 2017. Strategi Belajar-Mengajar. Syiah Kuala University Press.

Rinaldi, A. A., Daryati, D., \& Arthur, R. 2017.Penggunaan Media Pembelajaran Berbasis Audio Visual untuk Mata Pelajaran Konstruksi Bangunan.Jurnal Pensil: Pendidikan Teknik Sipil, 6(1), 1-7. 
Ruhaini Dwi Lestari, R. 2016. Bimbingan Keagamaan melalui Kajian Kitab Ta'lim Muta'alim dalam Membentuk Akhlak Santri (Penellitian di Pondok Pesantren Nihayatul Amal Putri Rawamerta Karawang) (Doctoral dissertation, UIN Sunan Gunung Djati Bandung).

Sumarni, N. 2017. Pengaruh Interaksi Edukatif dan Pemanfaatan Fasilitas Sekolah Terhadap Efektivitas Pembelajaran Pendidikan Agama Islam di SMAN Se-Kecamatan Tampan Kota Pekanbaru (Doctoral dissertation, Universitas Islam Negeri Sultan Syarif Kasim Riau).

Sutomo, M. 2019.Penerapan Reading Guide Dalam Pembelajaran Di Madrasah.Auladuna: Jurnal Prodi Pendidikan Guru Madrasah Ibtidaiyah, 1(1), 134-149.

Wulandari, D. 2018. Fungsi publik relations dalam meningkatkan perilaku konsumen dalam perspektif islam pada cv. Fariz digital printing bandar Lampung (Doctoral dissertation, UIN Raden Intan Lampung).

Wulansari, R. 2018. Pengaruh Penggunaan Lembar Kerja Peserta Didik Terhadap Efektivitas Pembelajaran Mata Pelajaran Ekonomi Sekolah Menengah Atas Negeri 3 Pekanbaru (Doctoral dissertation, Universitas Islam Negeri Sultan Syarif Kasim Riau).

Yanuarti, E. 2018. Pemikiran pendidikan ki. Hajar dewantara dan relevansinya dengan kurikulum 13. Jurnal penelitian. https://doi.org/10.21043/jupe.v11i2.3489

Yanuarti, E. 2019. Pola Asuh Islami Orang Tua dalam Mencegah Timbulnya Perilaku LGBT Sejak Usia Dini. Cendekia: Jurnal Kependidikan Dan Kemasyarakatan. https://doi.org/10.21154/cendekia.v17i1.1337

Zubaedi, Z. 2017. Buku Strategi Taktis Pendidikan Karakter (Untuk PAUD dan Sekolah). 